Article

\title{
Transnationalism among Second-Generation Muslim Americans: Being and Belonging in Their Transnational Social Field
}

\author{
Michelle Byng \\ Department of Sociology, Temple University, 1801 N. Broad Street, Philadelphia, PA 19122, USA; \\ mbyng@temple.edu
}

Received: 15 June 2017; Accepted: 25 October 2017; Published: 30 October 2017

\begin{abstract}
An increase in transnationalism, the ability of individuals and families to travel and maintain relationships across national borders, has led to questions about its impact on identity especially for the children of migrants. When combined with concerns about global and national security such as those that are associated with Muslims and Islam, then questions about the strength national identity are particularly pertinent. This analysis uses the theories of transnational social fields and intersectionality to examine the transnational experiences of second-generation Muslim Americans. It relies on qualitative interview data. The data show the intersection of their national, religious, and gender identities. It demonstrates that they experience transnational being in their parents' country of origin and belonging in the United States. Nationality, religion, and gender influence what they experience in each location. The analysis demonstrates the stability and centrality of American national identity in what second-generation Muslims experience in both locations. Moreover, their belonging in the United States rests squarely on their perceptions of themselves as Americans and their construction of their Muslim identity as an American religious identity.
\end{abstract}

Keywords: transnationalism; second generation; Muslim Americans; being; belonging; social fields

\section{Introduction}

This analysis addresses identity among second-generation Muslim Americans. Through an examination of their transnationalism (i.e., experiences in the United States and their parents' country of origin), it questions their identity construction. Specifically, how does transnationalism inform expressions of religious, gender and national identity among second-generation Muslim Americans? Increases in transnationalism have led to social theory and research addressing identity as it relates to social membership (i.e., being and belonging) within a transnational social field (i.e., the nations of origin and residence) (Levitt and Schiller 2004). Scholarship on transnationalism takes in to account intersectionality or the multiple identity categories that inform experiences (Crenshaw 1991; Collins 2000). Research that addresses the second generation (i.e., the children of migrants) focuses on their participation in transnational practices and the influence of transnationalism on their identity (Levitt and Waters 2002). With regard to second-generation Muslims and transnationalism, there are analyses of identity especially as it relates to religion. Questions have been raised about the implications of transnationalism among Muslims in the West given Islamic terrorism. Research addresses the compatibility of Islam with western cultural values (Mandaville 2009; Mandaville 2011) and the possibility that Muslims in the West might use Islam rather than western laws and values to determine appropriate behaviors (Bowen 2004). While migration to western nations solidifies religious identity among Muslims, it does not necessarily lead to a corresponding increasing religious practice (Voas and Fleischmann 2012). Although parents are likely to invest in the religious upbringing of their children, second-generation 
Muslims do not necessarily incorporate the cultural background of their parents in their practice of Islam (Voas and Fleischmann 2012).

One consequence of transnationalism is that identity is influenced by social relationships that are maintained across national borders and in more than one national context. In other words, by definition transnationalism means " ... identities and cultural production reflect their multiple locations" (Levitt and Schiller 2004, p. 1006). Transnationalism is carried out in places of attachment, signaling a " ... complex set of conditions that affect the construction, negotiation and reproduction of social identities" (Vertovec 2001, p. 573). Identity as a social construction rests on the view that societal circumstances, the reactions of groups and individuals to circumstances, and the relationships between groups and between individuals (often with regard to group membership) are the sites where the meanings of an identity are constituted and assigned (Lawler 2008; Berkhus 2008; Gergen and Gergen 2007). Identity can be understood as characteristics that individuals have in common, as the foundation of shared political interests, and/or as the basis for collective action (Brubaker and Cooper 2000). What identity references in this analysis is the relationship between self-understanding and social location or situational subjectivity. Situational subjectivity refers to "... one's sense of who one is, of one's social location, and of how (given the first two) one is prepared to act (Brubaker and Cooper 2000, p. 17)." Understanding how second-generation Muslim Americans understand their identity given their transnationalism is especially pertinent. International political conflicts inform their religious identity. Yet as it the case with other Americans, political rights and obligations are associated with their citizenship and nationality (Faist 2000; Tilly 2003).

This analysis expands our understanding of transnationalism among second-generation Muslim Americans through a comparative analysis of what they say about their experiences when visiting their parents' country of origin and what they say about their American identity. It contrasts their experiences of being in their parents' country of origin with those of belonging in the United States. It notes the intersection of the respondents' religious, gender, and national identities to what they experience in their transnational social filed. The role that Muslim identity currently plays in international conflicts and the suspicions that surround Muslims in the United States since the 11 September 2001 terrorist attacks on the World Trade Center in New York, signal the need for continued research addressing how second-generation Muslim Americans understand their nationality. Qualitative interview data show the importance of national identity for second-generation Muslim Americans. The comparative social filed analysis expands our understanding of transnationalism among second-generation Muslim Americans by demonstrating that nationality is central to their identity in spite of the social and political conflicts that surround their religion. In contrast to past research, the analysis demonstrates that second-generation Muslim Americans do not simply rely on western values of religious freedom to validate their Muslim identity (Zevallos 2008; Henkel 2004; Salih 2004). Nor do they say that there is a parallel between western values and Islamic values that legitimates their religious identity (Schmidt 2004). What they say is that they live by American values and other Americans should too. Moreover, they do not become American as a result of vising their parents' country of origin (Purkayastha 2010). Instead, they arrive as Americans and they are American for their entire visit. They are appreciative and respectful of the bonds of family and the public visibility of Islam, but their interpretations and reflections are filtered through the fact that they are American. Finally, while the young women are consciously aware of restrictions on their activities in their parents' country of origin because they are female (Purkayastha 2010; Mirza 2013), the young men experience restrictions too. However, the explanations that the young men offer are not related to their gender.

The literature review that follows begins with the theories of transnational being and belonging, social fields, and intersectionality. These theoretical concepts are used to guide the analysis. Research literature on second-generation Muslims, transnationalism and the second generation, as well as transnationalism and intersectionality are reviewed. After describing the data collection and analysis methods the findings on transnationalism and second-generation Muslim Americans are presented. Second-generation Muslim Americans experience transnational being in their parents' country of 
origin and belonging in the United States. Their experiences are informed by the intersection of their national, religious, and gender identities. Their American national identity, as opposed to their religion, is central to their transnationalism and their belonging in the United States.

\section{Theoretical Context and Background}

\subsection{Theorizing Transnationalism: Being, Belonging, and Intersectionality}

Transnationalism captures the production of identities and cultures in multiple national locations (Levitt and Schiller 2004). It addresses the ability of migrants and subsequent generations in the families of migrants to participate in transnational social fields or networks of social relationships where resources, practices, and ideas are exchanged between migrants and non-migrants. Social fields do not discount the significance and durability of national borders. They take into account the ease with which geographical boundaries are crossed as well as the relationships and social practices that cross national borders with migrants. Participation in social fields varies in terms of being and belonging (Levitt and Schiller 2004). Being describes social relationships that do not impact identity. Social participation is characterized by simple engagement in relationships and practices. Individuals can be in a social filed or participate in social relationships where the cultural politics of those relationships are not an enduring part of how they define themselves. Even with regular participation, for ways of being to become belonging requires identification. Belonging, on the other hand, is about conscious participation that signifies connection and identification. Belonging is grounded in institutionally based actions that are the foundation for identification. In other words, belonging is expressed when cross border relationships and practices are used by an individual to express who they are (Levitt and Schiller 2004). These two concepts have allowed researchers to understand how formal and informal cultural, social, and religious practices in both nations of a social field influence experiences, the creation of meaning, and identity among migrants and their children (Levitt and Jaworsky 2007; Vertovec 2001).

The ability to maintain relationships across national borders has resulted in transnationalism becoming as influential to scholarship about migrants and immigration as are theories about assimilation, acculturation, and minority group inequality (Levitt and Jaworsky 2007; Waters 2014). Transnational migrants are socially embedded in multiple locations, sites, and modes of communication. They participate in organizations that assist in their settlement and that facilitate maintaining ties to their home country (Lacroix 2014). Familial, economic, political, cultural, and religious ties to country of origin influence identity and experiences in country of settlement for both migrants and their children (Gardner and Grillo 2002). Communication technologies, the ease of international travel as well as neoliberal political and economic relationships within and between countries have prompted some nations to redefine citizenship in light of transnationalism. However, other nations are wary of the influence of transnationalism on the assimilation and national identities of migrants and their children (Waldinger and Fitzgerald 2004; Heath 2014).

In nations such as the United States where the national loyalty of non-whites is questioned, transnational ties even among citizens can give rise to questions about loyalty (Waldinger and Fitzgerald 2004). In general, maintaining ties to the home left behind reorganizes family relationships in light of economic responsibilities (Osirim 2011; Binaisa 2013), gender roles (Das Gupta 1997; Fouron and Schiller 2001; Fouron and Schiller 2001; Viruell-Fuentes 2006) and religious identities (Abdelhady 2006; Al-Ali 2002) as they are carried out in both nations. Economic and business opportunities in the United States can provide resources for communities in migrants' home countries and for the revitalization of urban American neighborhoods (Osirim 2011). Migrant women in the United States become the carriers of ethnic culture (Das Gupta 1997) as well as the primary sustainers of family ties between both nations (Fouron and Schiller 2001). For first- and second-generation women in the United States, transnationalism has both liberatory and non-liberatory aspects. On one hand, it facilitates across generation integration into the United States and, on the other, transnationalism 
supports the maintenance of traditional gender roles (Viruell-Fuentes 2006). In addition because of the convergence of global, national, and local politics around Islam, Muslims and other Americans are conscious of the group boundary that marks Muslim identity (Abdelhady 2006; Al-Ali 2002). For the second generation, relationships with family members in their parents' country of origin, even without actual visits, allows them to develop a transnational identity (Viruell-Fuentes 2006; Louie 2006).

Intersectionality has expanded the analysis of transnationalism as it relates to identity. Intersectionality theory proposes that socially constructed identities categories, such as gender and race, organize social differences and inequalities (Crenshaw 1991). As a social theory, intersectionality captures how social devisions or categories work in concert to shape the lives of individuals and socially recognized groups (Collins and Bilge 2016). Identity categories and their resulting social consequeces expose and legitimate group-based resource and status inequalities (Crenshaw 1991). Global and national relationships of domination and subordination (i.e., matrix of domination) reveal the connection between transnationalism and intersectionality (Collins 2000). In other words, categories of inclusion and exclusion are just as informed by nationality as they are by other identities. The status that is assigned to a particular national identity is determined by the political and economic relationships between nations (Collins 2000). Transnationalism and intersecting identity categories inform the experiences of second-generation Muslim in the United States and when they visit their parents' country of origin.

\subsection{Second-Generation Muslim Americans}

In the United States research has focused on the ability of religious institutions to facilitate the reformulating ethnic identity to allow for assimilation (Wuthnow and Offutt 2008; Cadge and Ecklund 2007). Religion is argued to be one site where the second generation defines their identity with regard to the ethnic culture of their parents and their own nationality (Levitt and Jaworsky 2007; Cadge and Ecklund 2007). These general findings are complicated for second-generation Muslim Americans by national and global security policies that are enacted in the aftermath of the $9 / 11$ terrorist attacks (Cainkar and Maira 2005). Islamic values, rather than those of western nations, are thought to guide the behaviors of some Muslims in the West (Bowen 2004; Grillo 2004). A shift toward Islamic values among the second generation is argued to be an outcome of national security policies that marginalize young Muslims (Mandaville 2009; Voas and Fleischmann 2012).

Racialized immigration policy and racial profiling results in Muslim Americans experiencing an infringement on their citizenship and belonging following 9/11 (Ahmad 2011). This finding is in contrast to the classic research that positioned Muslim immigrants and their religious institutions as similar to those of other ethnic immigrants to the United States (Haddad and Lummis 1987). However, the paradox of racializing Arab Americans with regard to their religion rather than by phenotype occurred prior to 9/11 (Naber 2000). As a direct result of post-9/11 security policies, young adult Muslim Americans are aware of not having the privileges of white race and of being socially positioned like other Americans who are not racially white (Alimahomed 2011). Anti-terrorism policies criminalize Muslims as persons who are not just culturally different but who hold beliefs that are opposed to core American values (Cainkar and Maira 2005). Given the global power of the United States and the association between Islam and terrorism, young Muslim Americans may construct forms of citizenship that are flexible, multicultural, polycultural, and dissenting (Cadge and Ecklund 2007). More importantly, their transnationalism maybe perceived as a national security risk to the United States that raises questions about their national loyalty (Maira 2004; 2008).

\subsection{Transnationalism and the Second Generation}

Transnationalism provides the second generation with a set of social relationships and/or a consciousness of global dynamics that inform their identity (Mandaville 2011; Salih 2004; Easthope 2009). Both citizenship and group boundaries shape their belonging in their parents' country of migration (Thomson and Crul 2007). However, visiting their parents' home country can increase 
their identification with that nation and decrease their identification with the nation where they are raised (Schimmer and van Tubergen 2014). Research on transnationalism among second-generation Muslims has focused primarily on Europe and Australia. These analyses highlight the influence of identity and values in the second generation's experiences of transnationalism. A comparative analysis of second-generation Muslims in the Demark, Sweden, and the United States specifically focuses on transnational identity formation. Research on second-generation transnationalism in the United States addresses its influence on female gender roles. The following begins with the transnational research on second-generation Muslims and then turns to that on second-generation women.

Second-generation Iranians think of their religious and national identities as synonymous (McAuliffe 2007). In contrast to the Baha'i, being Muslim makes them legitimately Iranian. As a result they deemphasize their Muslim identity. A comparative analysis of the Latin American and Turkish second generations in Australia finds that both groups have a sense of not fully belonging (Zevallos 2008). However Islam provides a pan-ethnic identity for those who are Turkish and Muslim. Yet when they visit Turkey their Australian identity is more important than their Turkish one. In other words, being Muslim is more important than being Australian but being Australian is more important than being Turkish (Zevallos 2008). Although they feel excluded in Australia, they also feel that they benefit from the nation's egalitarian ideals. A comparative analysis of second-generation Turkish Muslims in Turkey and Germany yields similar findings about social values. In both nations secularism in combination with the ideals of religious freedom allows them to practice Islam (Henkel 2004). An ethnographic account of a second-generation, young adult Muslim man in Italy yields similar findings. He legitimates his Muslim identity with universal values that go beyond a respect for difference (Salih 2004).

A comparative analysis of identity formation among second-generation Muslims in Demark, Sweden, and the United States about perceptions of western values in relation to Islam yields similar findings (Schmidt 2004). Western cultural values and democratic ideals allow for religious choice. In addition those values call for morally and ethically correct behaviors that are consistent with the values of Islam. As a consequence second-generation Muslims can practice Islam based on those values without the culturally informed religious practices of their parents. Alternately, they can adhere to western values that call for moral and ethical behaviors without Islamic religious practice and still lead a life that is consistent with their religion. Identity formation among second-generation Muslims in western nations is informed on one hand by their visibility and, on the other, in their relationships and conversations with one another (Schmidt 2004; Kibria 2008). The higher levels of religiosity among second-generation Muslim Americans in comparison to their parents correspond to their perception that Islamic values are consistent with American values of justice and equality (Cainkar 2004). The global and national contexts of Islam combine to create the transnational experience of religious identity for second-generation Muslims (Schmidt 2004).

The transnational experiences of migrant and second-generation women in the United States are defined by their roles as the carriers of ethnic culture (Das Gupta 1997) and the primary sustainers of family ties between both nations (Fouron and Schiller 2001) Transnationalism has liberating and non-liberating aspects for women. It can impose traditional female gender roles that subordinate women and it can provide second-generation women with an ethnic culture to combat western racism (Das Gupta 1997; Viruell-Fuentes 2006). For Haitian women transnationalism provides opportunities for political activism in Haiti while maintaining classic female gender subordination within their families. In other words, their family relationships reinforce gender inequality across their social field in spite of their transnational political activism (Fouron and Schiller 2001). Research on South-Asian Indian women demonstrates that their transnationalism frames the creation an authentic ethnic identity. First-generation women engage in the invention of ethnic authenticity that they impose on the second generation. Although the second generation rebels against the first generation's efforts, both generations of women are responsible for maintaining their community's ethnic identity (Das Gupta 1997). For second-generation Mexican women transnationalism allows them to 
adopt an ethnic, rather than a racial, identity in the United States (Viruell-Fuentes 2006). Even without visits to Mexico, their transnationalism means that second-generation Mexican women can position themselves outside of U.S. racism (Viruell-Fuentes 2006). In general, the transnational roles of firstand second-generation women facilitate across generation integration into the United States while supporting traditional female gender roles.

\subsection{Transnationalism and Intersectionality}

Intersectionality provides a more detailed analysis of transnationalism as it relates to identity. It expands the analytical lens of transnationalism to reveal the potential for an individual to live a life that is characterized by both majority and minority statuses (Purkayastha 2010; Purkayastha 2012). Moreover, transnational intersectionality allows for analyzes that take into account the racialization of religion and therein the ability of religion to inform the social relationships of domination and subordination (Purkayastha 2012). Recognizing this is particularly important for Muslims given their transnationalism in combination with national and global security policies that are directed toward them. Muslims' experiences of religion-based marginalization in the West in combination with gender-based marginalization of Muslim women speak directly to the transnational aspects of the "matrix of domination" (Collins 2000; Purkayastha 2012). Connecting intersecting identity categories to locations reveals contradictions in how identities are influenced by social structures as well as how they are experienced by individuals (Anthias 2012; Anthias 2008). Research demonstrating the inability of the South Asian and Muslim middle-class second generation to access American identity in spite of the parents' economic resources is evidence of transnational intersectionality. Their transnationalism provides them with other national foundations for their identity given the limits on their access to American identity in the United States (Purkayastha 2010). Muslim women living in western nations experience intersectionality given western cultural discourses about their religion and gender-based subordination of women. Although Muslim women's perceptions of themselves are different from how they are perceived by others in western nations, what they experience in their day-to-day lives are the implications of being thought of as dangerous, oppressed, or the embodiment of modesty. Others' perceptions of the intersection of their religious and gender identities shape their social experiences (Mirza 2013). Transnational intersectionality takes into account the possibility that participation in social norms, social relations, and elements of culture may be instrumental rather than an expression of identity (Anthias 2012). However, such participation can also indicate shared collective narratives of self and other that signal belonging and identity (Anthias 2008).

It is this context signals the need to further our understanding of transnationalism among second-generation Muslims Americans. Past research indicates that the second generation may experience some degree of bifurcated membership between the locations of their transnational social field. Research signals that anti-terrorism policies have negatively influenced the social membership of Muslims in the United States, including the second generation. These findings warrant a closer examination of how second-generation Muslim Americans understand their transnationalism. What do second-generation Muslim Americans say about their visits to their parents' country of origin? What do they say about their American identity? How does transnationalism inform expressions of religious, gender and national identity among second-generation Muslim Americans?

\section{Data and Methods}

Qualitative interview data is used to demonstrate what second-generation Muslim Americans experience in the locations of their transnational social field. Interviews were conducted between 2005 and 2009 with Muslim Americans living in Philadelphia, Pennsylvania USA and the surrounding suburbs. Philadelphia is home to a visible racially and ethnically diverse population of indigenous and immigrant Muslims. The Association of Religious Data Archives estimates the Muslim population in Philadelphia in 2010 at 39,540 or 26 out of every 1000 persons (Grammich et al. 2010). Respondents were 
recruited for this research based on their Muslim identity and their second-generation status. In other words, their parents had migrated to the United States.

This analysis is based on forty-seven interviews (thirty female and seventeen male respondents). Sixty percent of the interviewees were born in the United States and twenty-three percent are naturalized citizens. Only ten percent reported having a high school education, while fifty-five percent were currently enrolled in an undergraduate program. Eighty-one percent were between the ages of eighteen and twenty-three. Respondents were most likely to identify themselves as upper-middle class or wealthy (forty percent) and fifty-one percent reported household incomes above $\$ 65,000$ a year. They are overwhelmingly of South Asian (68\%) or Middle Eastern descent (21\%). The parents of South Asian respondents are from Bangladesh, Pakistan and India. Middle Eastern ancestry is Palestinian, Syrian and Saudi Arabian. Six percent of respondents are of North African ancestry (Morocco and Egypt) and four percent have parents from West Africa (Liberia and Ghana). Forty-nine percent identified themselves as Asian, four percent as Black, four percent as White, thirteen percent said they were "in between" race categories and thirty percent chose a hyphenated identity such as Pakistani-American. I recruited study participants by attending and participating in organizational events held by the Muslim Students Associations at local college and university campuses, annual and monthly events held by the Council on American-Islamic Relations, Council for the Advancement of Muslim Professionals and other local groups, as well as attending events held at mosques in the city and surrounding suburbs.

Muslim identity is salient enough for the respondents to agree to participate in this project based on that identity. Their religiosity can be assessed through their responses to self-administered survey questions about religious practice. Their answers indicate that they are similar to Muslim Americans who participated in two Pew Research Center nationwide surveys (Pew Forum on Religion and Public Life 2007; Pew Forum on Religion and Public Life 2011). The participants in this project are more likely than those in either Pew study to say that they prayed five times a day and less likely to say that they never prayed (Table 1). They are more like the 2007 than the 2011 Pew respondents in terms of attending religious services. Eighty-seven percent of the respondents in this research indicated that they did fast during the month of Ramadan. Nineteen percent said that they read the Quran daily and $45 \%$ read it frequently. Overall, what the participants in this project say about their religious practices indicates that they similar to other Muslim Americans in terms of religiosity.

Table 1. Religiousity (Percent).

\begin{tabular}{|c|c|c|c|}
\hline & Respondents & Pew 2007 & Pew 2011 \\
\hline \multicolumn{4}{|l|}{ Prayer } \\
\hline Five Daily & 57.4 & 41 & 40 \\
\hline Fewer Daily & 8.5 & 20 & 20 \\
\hline Less Often & 29.7 & 26 & 29 \\
\hline Never & 4.2 & 12 & 10 \\
\hline \multicolumn{4}{|l|}{ Service Attendance } \\
\hline Weekly & 38.3 & 34 & 47 \\
\hline Monthly & 29.8 & 29 & 41 \\
\hline Seldom/Never & 31.3 & 37 & 11 \\
\hline \multicolumn{4}{|c|}{$\begin{array}{l}\text { Sources: Pew Forum on Religion and Public Life Pew Forum on Religion and } \\
\text { Public Life (2007): Prayer is for all US Muslims (p. 25). Note: Service Attendance } \\
\text { is for native born not African American (p. 24). The Pew category "less } \\
\text { often" is reported here as monthly attendance. Pew Forum on Religion and } \\
\text { Public Life (2011): Prayer (p. 25) and Service Attendance (p. 26) are for those } \\
\text { who are native born not African American. }\end{array}$} \\
\hline
\end{tabular}

Atlas-ti qualitative data analysis software was used to code and organize responses to interview questions by themes. Atlas-ti assigns numerical labels to coded sections of interview transcripts. 
Those labels are included with the interview quotes that are presented in the analysis below. Interviews lasted for one to two hours and covered a range of topics: immigrant narratives, family and friendship relationships, 9/11 policies, media and Muslims, national origin discrimination, religion-based discrimination, American identity, Islam in the United States, and Muslims in the United States. All of the interviews were conducted and coded by the author. Interviews were recorded. They were transcribed by student research assistants. This analysis draws on what respondents say about visiting their parents' country of origin and their statements about their Muslim and American identities. It relies on data that were coded to highlight respondents' comments about the following topics: (1) the respondents' overseas family, (2) their family in the United States, (3) family ties: emotional ties and religious ties, (4) experiences in their parents' home county, (5) return travel to the United States, (6) Muslim identity in parents' home country, (7) Muslim identity in the United States.

The following analysis begins with what respondents say about visiting their overseas relatives. It notes what they say about their family relationships and how they experience their religion while traveling. Their comments are consistent with transnational being. They are engaged in social relationships and practices. However their engagement does not have a sustained impact on their identity. The analysis then turns to their belonging in the United States. It is expressed in the contrasts that they draw between themselves and their parents as well as the connections they make between their Muslim and American identities. It is important to note that interviewees were not asked to compare their transnational experiences to their lives in the United States. Nor were they asked to connect or compare their Muslim and American identities. The connections and comparisons appeared in how they structured their responses.

\section{Results}

The following analysis demonstrates that the intersection of the national, religious, and gender identities informs the transnationalism of second-generation Muslim Americans. Their descriptions of experiences in their parents' countries of origin and their understandings of their American identity demonstrate how they position themselves in their transnational social field. What they say about their visits to their parents' home country is consistent with transnational being. They are engaged in social relationships and practices, but those activities do not have a sustained impact on their identity. They are consciously aware of the difference between what they are experiencing and their lives in the United States. Their engagements are instrumental; they are simply participating in the social relationships of the moment. In contrast, their belonging in the United States is demonstrated in their use of core American values to construct Muslim as an American identity. Their comments go beyond the ideal of religious freedom to position themselves culturally within the pantheon of American citizens. This allows them to identify as both American and Muslim simultaneously and without contradictions. What they say indicates that they have the same social membership as other Americans.

\subsection{Transnational Being: Family Makes It Home}

How second-generation Muslim Americans experience, understand, and conform to family expectations in their parents' home country highlights their transnational being and intersectionality. They are consciously aware that they are visitors who are a part of their parents' family. They are living with their extended family, who can be strangers. They are engaged in family relationships and they have a sense of family membership, but their circumstances are temporary. Their American lives inform their understandings and interpretations. They are engaged in transnational being that is informed by the intersection of their nationality and gender identities.

In describing their visits overseas respondents say they are at home signaling the emotional connection and permanence of family relationships. Visiting family means that they are among different people but a bond exists between them because they are relatives. Alia describes the households of her four uncles who all live in the same apartment building. She notes everyday family conflicts as well as how she and her siblings are positioned as family members. 
"So like there's always some discussion about cutting trees in the front yard or some argument about who put the trash in the wrong place and a cat got in it and made a mess or something like that. So they were very sweet to us, me and my brother and sister, when we went and all of them made us feel like we were at home. But between the families themselves they have the same problems [as other families] ... " $(5: 3 ; 18: 18)$.

Alia describes the normalness of family conflicts while making it clear that she is comfortable in spite of them. Her comment hints at the hospitality that is extended to visitors and to the minor everyday tensions of family life. Foofer makes a similar comment. She is aware that she is in an unfamiliar set of relationships. She knows that she should be uncomfortable but she says that she is not.

"So I didn't feel that awkward. Oh, I'm living with people I've never met before. ... I felt just very comfortable with it and I stayed with my mom's sister ... I felt extremely at home even though I was traveling, just because I was with such close family members." $(25: 12 ; 23: 24)$.

For Foofer what is significant is that she among relatives rather than the fact that her relatives are strangers. Her bond to the people she is visiting is based on their relationship to her mother. As a result, her sense that she is a member of the family is not disrupted by the fact that she does not actually know them. Ali's comment is like those of Alia and Foofer, although his focus is on how family membership is extended to him.

"Like um, they saw me as still one of them. They didn't treat me like an outsider ... [I]f I was at my aunt's house, I was like her son, you know. They were like, come closer." $(4: 6 ; 124: 134)$.

Alia, Foofer, and Ali present what seems to be a paradox: they are visiting strangers but they experience the bonds of family. They describe relationships where they are identified as family members by others and they identify themselves as family members. The emotional bonds of family membership are a part of their transnationality although the practical side of knowing their relatives is absent. What they experience is transnational being. The experiences are important but they do not inform their identity. They aware that their relatives are strangers to them and they are strangers to those they are visiting. Their expressions of emotional connections demonstrate transnational being because the actual relationships of emotional bonding are absent. The emotionally grounded family relationships that exist with their parents are instrumentally extended to their transnational relatives.

There is a practical side of the second-generation's family membership also. They must conform to family rules and expected behaviors. What they say about expected behaviors highlights the differences between their American lives and their experiences abroad. Through comparisons they demonstrate the intersection of their American and gender identities. Although Ahmed and Alia provide similar statements what they say is informed by gender and explained through the lens of their American identity.

Ahmed says about his overseas family, "They want to know what you're doing at any moment of time, but it's perfectly fine." He goes on to provide details that are juxtaposed to his American life:

“It's not like here where I could go out with friends at night ... [T] heir family life is really oriented around be there at meal times, be there so you can communicate to each other. There's no, like as you can see our house is designed in a way where we have our bedroom sort of shut. Over there they hardly use their doors and everything is open. They know who's where and at what sort of times and things like that." $(2: 3 ; 32: 34)$.

Ahmed is aware of and conforms to how he is expected to behave by his overseas family. He contextualizes the differences in social relationships through the architecture of houses. He tells us 
about differences in how family members interact with one another. He is conscious of differences with regard to privacy and that he is afforded more privacy in the United States.

Like Ahmed, Alia is also aware of more restrictions on her ability to be outside of the house and among friends when she visits her family. Note her description of going out and the role of gender in what she experiences:

"And they want to make sure, especially me and Aisha my sister ... that we come home at a good time; we're not coming home late and if we come home late that at least our brother or cousin is with us ... Here my parents, they want to know where I'm going. They want to know what time I'm coming home. But they're not so when I come home, 'Where were you? What were you doing?' They don't really do that." (5:4; $24: 24)$.

Both Alia and Ahmed conform to expected behaviors when they visit their relatives. They are conscious of the fact that they must provide an accounting of where they have been and what they were doing. They are both aware that there are restrictions on being out at night. For Ahmed the restrictions are about being available to participate in family interactions, while for Alia the restrictions are about her gender identity.

Although the practical side of what is expected of them is the same, the gender implications are different. The meaning and experiencing of Alia's gender identity is reoriented transnationally. She moves from being a person who simply needs to let her parents know where she is to being someone who is socially defined as unable to be public at night without a male relative. Additionally, Ahmed and Alia describe a similar freedom in their American life that they both say is absent in their parents' county of origin. They express a similar type of freedom to be out and among friends when they are in the U.S. This common characteristic of their American lives leads to a similar experience when they are in their parents' country of origins even though their explanations for the experience are different. For Ahmed it is about family relationships while for Alia it is about her female gender.

In their parents' home country second-generation Muslim Americans express an emotional connection to their relatives and a willingness to adhere to expected behaviors. Not actually knowing their relatives seems to be an anomaly in their visits to their parents' country of origin. However, it is not because their transnational being rests on the family bonds of their parents rather than their own. Their transnational being is expressed in their use of their American lives, or their national identity, as the comparative reference point for their experiences. In other words, what they say about their family relationships demonstrates transnational being or engagement that does not have an impact on their identity. The importance of their national identity and its intersection with their gender identities is expressed in how gender informs family relationships and the ability to go out. Second-generation Muslim American men and women face restrictions on going out in their parents' country of origin. However, their explanations the restrictions are different. In contrast, they provide similar descriptions of personal freedoms in the U.S. As second-generation Muslim Americans they have the freedoms of simply hanging out with friends or shutting their bedroom door that are common among American young adults without regard to gender.

\subsection{Transnational Being: Sights and Sounds of Public Places}

For second-generation Muslim Americans, transnational being in their parents' home country extends beyond family relationships to incorporate non-English language skills, the public visibility of religion, and their perceptions that they are identifiably American. What the respondents say indicates engagement in and an appreciation of what they are experiencing, but those experiences do not have a sustained impact on their identity. Their public place experiences and interactions are informed by the intersection of their national and religious identities. They are consciously aware that they are American and how it informs their interpretations and experiences. They are very appreciative 
of sharing the religious identity of those around them, but this does not displace the importance of their nationality.

The ability to speak the native language of their parents' home country informs the second generation's sense of shared ancestry and a connection to their surroundings. This is evidenced in a comment by Foofer: " ... [W] hen I got to India everyone was speaking in like Urdu and Hindi. So that was comforting because that's what I speak at home. $(25: 11 ; 21: 22)^{\prime \prime}$. Note that her statement about "home" refers to the United States. Comments from Ali and Laila signal the importance that the second generation places on language to assess their membership in their parents' home country. Ali says:

“I was very nervous because I'd lost my language, basically. I can still speak it, but broken up. So basically, it was me speaking my own language with an English accent. So I was very nervous, but they made me feel like I was really home. So it was great." (4:4; 84:94).

Ali identifies a language other than English as his own; that English is his primary language is a source of embarrassment for him. Laila's comment is similar, she says: “ . . The language barrier is a big thing for me, because like I don't really know my native language very well" (36:15; 69:79).

For Ali, Laila, and Foofer language skills are part of their transnational being. They think of language as an indication of shared ancestry. Variations in their skills mean that they are positioned differently in social relationships when they are in their parents' country of origin. Foofer's is comfortable, Ali feels accepted because his American accent is overlooked, and Laila feels that the inability to speak her "native language" creates social barriers for her. Even though language is thought of as an indication of shared ancestry, their American nationality informs those skills. Foofer can speak Urdu and Hindi because it is spoken by her family in the U.S. In other words, the defining factor with regard to their language skills is not their ancestry but their lives in the United States.

Another societal site of transnational being in their parents' home countries is the public visibility of Islam. The second generation appreciates that their religion is a part of the nations they visit and they recognize it as a significant indication that they are in a different country. However, their American identity informs their understanding of what it means to have religion be an everyday part of public life. What they say indicates recognition and engagement (i.e., transnational being), but the intersection of their American and religious identities informs how they understand public place religion. Note Aminah's comment:

"Okay, um over there they like play [the call to prayer] for every prayer and you can hear it.... I'd wake up at [dawn prayer] time hearing that. I loved it. ... [I]t was very, that was very nice [and] meeting people talking Arabic as opposed to English. That was pretty interesting, because I understand Arabic a lot better than I speak it. I really liked it, a lot ... [B]ut also, I don't know if I'd go to like live there or something like that because I'm so used to it here." (7:1;40:49).

Aminah's appreciation of the public visibility of Islam is clear; she loves being a part of the sights and sounds of her religion. This does not displace her American identity. Moreover, because she is American she doubts that she could actually live in a Muslim country. Leena's comment is similar but she is more direct in saying that her American identity means that in her parents' country of origin she is a visitor only. She says:

“Well, I just, I like being there just for the fact that it's a Muslim country ... [Y]ou hear the [call to prayer] from the mosque. I like that and I like having the Arabic people everywhere and you are just one of them. But I still didn't feel like I was one of them, you know because I was from America ... I think differently." (37:1; 62:86).

Leena enjoys being a part of the crowd of people who share her religious identity and her ethnic ancestry. Yet she is keenly aware that her American identity shapes who she is all the way down to 
the level of her consciousness. Leena and Aminah feel emotionally connected to the Islamic culture that surrounds them, but they are temporary participants in those environments. Their ancestry and their religion allow them to be comfortable with their experiences. However their interpretations, their understandings, and how they position themselves socially are tempered by the fact that they are Americans.

A third indication that the second generation experiences being in their parents' home country is their perception that they are identified as American by other people. Laila describes being in a Pakistani marketplace with her mother when she was a little girl.

"They definitely see that I'm foreign. I mean it just seems like the way that foreigners carry themselves ... people seem to pick that up really quickly. And I remember when I was young ... the beggars would come up to us ... [T]hey seem to know that we were foreign and that we had money. And I was like Mommy, how do they know this? She [said], 'I don't know, it's just the way we carry ourselves, it's just different.'” (36:15; 69:79).

That Laila is a "foreigner" is evidenced in her demeanor. Even as a small child she is aware that her American identity is readily observable, although she is not certain of how this is communicated. Nicole's experience is similar. Like Laila, being American makes her identifiable and, as a result, she experiences some discomfort when she is overseas. Nicole says:

"In Jordan, you get off the plane and everyone just kind of looks at you, like they know you're not living in Jordan. They know you're like from America or somewhere else. So when [I] come here (return to the U.S.), I feel more comfortable, [because] I was raised here, this is my home." (47:1; 25:29).

Laila and Nicole's perceptions that they are visibly American indicate that the option to adopt the national origin identity of their parents is not available to them. They are not moving across a boundary that gives them access to Jordanian or Pakistani identity because of their ancestry matches that of the people in the country they are visiting. In those countries they are always American. The visibility of their American identity is an aspect of their transnational being. The second generations' experiences are embedded in family relationships and cultural practices (e.g., language and religion) that frame transnational being in the societies they visit. However, their American identity defines how they interpret what they experience in the parents' home country.

When the second generation is in public in their parents' home country they are conscious of the religion and ancestry that they share with the people of that nation. Their sense that language is an indicator of shared ancestry and that religion is a marker of common identity allows them to experience transnational being. Even when they do not actually know the people they are visiting, family relationships allow them to feel comfortable. Who their parents are creates the connection of family bonds. They do what is expected of them by their family and they are aware of implications of female gender with regard to those expectations. They are very conscious of being an American, also. Their American lives are a continuous reference point in shaping how they understand and interpret of their experiences. The intersection of their national, religious, and gender identities informs their experiences in their parent's country of origin. They are engaged in social relationships and practices that do not have a sustained impact on their identity. This is in sharp contrast to their belonging in the United States.

\subsection{Transnational Belonging: Only in America}

Belonging in a social field is evidenced in practices that enact identity. It is demonstrated through a conscious connection that utilizes a society's core values to legitimate one's identity and social membership. The second-generation Muslim Americans who participate in this research see their Muslim identity as an American identity. They do not argue that American ideals of religious freedom give them the right to be Muslim. They say instead that the two identities are consistent with one 
another. There is nothing about being Muslim that is inconsistent with being an American and there is nothing about being an American that is inconsistent with being Muslim. They express their belonging by separating their religion from their parents' ethnic culture, by framing their religious identity as an American identity, and by using core American values and ideals to support their social membership and participation as Muslims. What they say demonstrates the intersection of their national, religious, and gender identities.

The second generation sees their parents' religious identity as firmly embedded in the cultures of their countries of origin. They distance themselves from this understanding of what it means to be Muslim and, in doing so, from their parents. Ahmed, for example, tells a generational story highlighting the differences in culture between himself and his father. It is symbolized in his father's need to eat rice with every meal and his willingness to eat rice or pizza. He comes to these conclusions about his identity.

"Whenever someone ask me what I am, I never say I'm Bangladeshi, I never say that I'm Arabian because I was born in Saudi Arabia. I do say I'm a Muslim ... So when you have these American values, it's not as extreme as double values, it's just a cultural lifestyle. But as long you don't violate your religious lifestyle, I believe it's perfectly acceptable." $(2: 6 ; 80: 82)$.

In naming his identity Ahmed says that he is Muslim but that does not indicate that he is not an American. His identity and culture are based in the fact that he is both Muslim and American. He can eat rice with his meals or pizza. His American and Muslim cultural repertoires do not compete with one another. They do not pose conflicts for him. Living in the United States provides him with a particular style of living that allows him to be Muslim also.

Alia's comments are similar to Ahmed's. She sees cultural differences as dividing Muslims because migrants long for the home they left behind, but this is not a longing that she shares.

"... [A] lot of people come from other countries and they're all Muslim but they choose to stay with those who are like them. ... I mean we all see that we're Muslim, but people relate more to people who are like them. If they miss their country, they'll be reminded of [it] if they have friends who are like them. They want their kids to marry people from the same ethnicity, so they stay around those who are like them. It's a difference that I wish wasn't there but it's so apparent in the Muslim community, the separation." $(5: 7 ; 64: 64)$.

Note that Alia is highlighting the boundaries between Muslims in the U.S. She frames those who are "like them" by pre-migration national cultures and not religion. From her point of view, pre-migration cultures divide Muslims among themselves and separate them from American society. Both Alia and Ahmed indicate that second-generation Muslim Americans can reject the influence of the country of origin cultures of their parents on their articulation of Islam. From their points of view, social boundaries exist among Muslims rather than between Muslims and American society. Alia and Ahmed frame their social belonging as culturally American and religiously Muslim.

Having been raised in the United States allows the second generation to be both Muslim and American. They see religion is one thing and culture is another. What amounts to religious practice can be specified, but religious practice need not be superimposed onto culture. This is reflected in the views of Ali and Eddie. According to Ali:

"When I say Muslim I don't see it as a cultural thing, I see it as a religious thing. There's no such thing as Muslim culture which would be the way they look, the way they dress, the way they act. ... [I]f you migrate, what does that have to do to with your religion? Culture will always change no matter where you go, you'll adapt [to] a new culture. But something that shouldn't change is your religion ... unless you seriously think that it's wrong for you." (4:7; 140:146). 
Ali is just as grounded in valuing his religious identity devoid of an articulation of Muslim culture as he is in the freedom to choose or reject religiosity. Religious practice is not culturally determined, nor is religion a culture in and of itself. Eddie's perspective is similar, religion can be influenced by culture but people who are raised in the United States are free to develop their knowledge of religion without relying on a reified Muslim culture.

"But if you came here and you were raised here from [when you were] little and you grew up with a lot of Muslims who were basically the same, then your views are not as much influenced by your culture. You sort of get a chance to develop, to go to the mosque, and to the MSAs [Muslim Student Associations], and stuff. You sort of explore and you read more about your religion and you find out [about it]." (10:9; 79:79).

Eddie places the second generation's development of their religious identity firmly within their American experiences. His comment signals the ability of the second generation to engage in religious practice free from the influence of their parents and in a way that is shared with their peers. In other words, he understands religion as contextualized. Being Muslim in the United States is informed by learning and practicing Islam in the United States.

Living in the United States is the foundation of the second generation's Muslim identity. Not only are they Americans, they are not isolated from American culture. They use American values and culture as references points for their identity. In comparing herself to Muslims who are new migrants to the United States, Aminah makes this clear.

“... [P]eople who come immediately from overseas, it's different for them; they still have grounding [in] how it was over there. But people like me [are] very Americanized. I don't have a lot of background culture in me. People who have grown up here [are] Americanized.... I think that once they realize that following the rules of the religion is what you're supposed to do then you can live your life around that. It's not a problem." $(7: 5 ; 81: 81)$.

Aminah puts forward a very clear articulation of belonging as an American. She embraces American culture in the same way that she embraces her religiosity. She has the ability to practice her religion because she is an American. Moreover, her religious identity is not tethered to a set of cultural practices that would signify that she is not American.

Second-generation Muslim Americans situate their religious identity as an American identity. They separate their religion from their parents' ethnic culture thereby making it compatible with their social reality and nationality. They see themselves as simultaneously culturally American and religiously Muslim. Their identities are not in competition with or opposition to one another. They make the case that American society informs their identity. In doing so, they demonstrate their belonging in the United States.

The intersection of the second generation's national and religious identities is demonstrated in their deploying American values and ideals to defend being Muslim, to support their social membership, and their participation. Even when the second generation acknowledges the global and national political conflicts around Islam that heighten perceptions that Muslims are a threat to American society, they position themselves as Americans. Fatima Syed notes the media and the political visibility of Muslims in combination with an assertion of her American identity.

"People think things about Muslims from what they see on television. We can show them that all Muslims aren't like that. We are Americans too and we're more like you than you think. ... [Ethnic culture is] disappearing also over time. I mean we are the second generation. [Ethnic cultural is] probably more evident in the first generation that came but not so much now. I think that'll continue [to] happen over generations." $(16: 5 ; 88: 91)$. 
Fatimah Syed is speaking directly to the media images that construct Muslims as different from other Americans. She positions Muslims as Americans while acknowledging that migrants have cultural backgrounds that are different from Americans. Her point is that these differences are not a factor for second and subsequent generations of Muslims who are culturally like other Americans. Moreover, she projects the Americanization of Muslims into the future. Consciously or subconsciously, she invokes the classic narrative of immigrant incorporation to project the inclusion of the descendants of Muslim migrants into American society.

Fatimah makes a similar argument, just a little more vehemently. She feels that it is important for Muslims to be visible participants in American society. She frames social participation as a political right and a necessity. Her comment highlights the intersection of her national, religious, and gender identities.

"I know for a fact that Muslims should be a part of their communities. If we're not there, than who [is going to] back up the stereotypes that we have? ... If you're not, who's there to ... stick up for us? If I wear hijab [a headscarf] and I'm hiding, than what's the use of

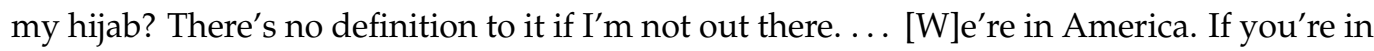
America, their rules are to be free. Practice your religion. So if that's what the Constitution is built upon, why not take it and move forward with it? ... We're in America. ... I don't believe you can be here and not be a part of them. Once you're in America and you're born here, you are an American. You're just cosigned with Arabia and before that you're American, you're a Muslim American." (17:7; 34:34).

Fatimah clearly connects Muslim Americans active participation in American society to Constitutional rights, religious freedom, and citizenship. What she says is the very definition of transnational belonging in a social field. She signals the primacy of American identity over inherited or "cosigned" ethnic identities. She notes the absolute necessity for Muslims to be active social participants like other Americans, especially in light of negative stereotyping of Muslims. Additionally, she presents an articulation of Muslim female gender identity that is empowered. For her wearing hijab is an expression of her political rights as an American. From her point of view, political engagement and participation are social responsibilities. She speaks to the very heart of American ideals of rights, freedoms, and citizenship.

Belonging characterizes how second-generation Muslim Americans position themselves in the United States. On one hand, they eschew the ethnic identities of their parents that would create a boundary between their American and Muslim identities. On the other, they construct their Muslim identity as an American identity. They define what it means to be Muslim from within the context of their American experiences. Most importantly they use the values and ideals of American society to support the legitimacy of their Muslim identity as well as their membership and participation in Americans society. They step beyond the political right to religious freedom to construct Muslim identity as an American identity.

The positions of second-generation Muslim Americans in each location of their transnational social field differ. The differences signal shifts in social context that highlight the second generation's American identity. Fatimah's comments about wearing hijab indicate that female gender is experienced very differently in the United States in comparison the how it is experienced in the respondents' parents' country of origin. When in their parents' country of origin female gender is experienced as limitations on being in public at night without a male relative. In the United States Fatimah uses hijab as an expression of her American identity and as an assertion of political rights. She has a right to be visibility Muslim and female in American society. Similarly Ahmed and Alia's comments make it clear that, in contrast to their parents, they are American. While their parents use ethnic identity to cling to their migrant origins, Ahmed and Alia seek to eliminate migrant group boundaries that would separate Muslims among themselves and from American society. The American comparative reference point that the second generation uses to frame their overseas experiences is grounded in a full understanding 
and identification of themselves as Americans. Although the second generation enjoys experiencing the sights and sounds of Islam while overseas, Ali and Eddie's comments make it clear that for them Islam is an American religion. It is a religion that they learn in the context of their American lives and that they can chose to reject. Just as the use of American points of reference and interpretation are expressions of transnational being when the second generation is in their parents' country of origin, their insistence that their religion be framed, constructed, experienced, and understood from within the context of their American lives is an expression of belonging in the United States. For the second generation, Islam is not about the experiences and cultural references points of their parents; instead it is about who they are as Americans.

\section{Concluding Remarks}

The above analysis examines how second-generation Muslim Americans experience transnationalism. It uses qualitative interview data to assess what they say about their experiences in both locations of their transnational social field (i.e., their parents' country of origin and the United States). The intersection of their national, religious and gender identities inform their experiences in both places. In their parents' country of origin their transnational being highlights the importance of their nationality to their experiences. Not only are their American lives a continuous reference point for meaning making and interpretation, they are consciously aware that being an American makes them different from their relatives. They enjoy the public place visibility of their religion, but this is not enough to make them want to live in those countries. In addition, while they understand and accept the restrictions that are placed on young women because of their gender, young men simply offer a different explanation for similar restrictions that are placed on them.

In contrast, their belonging in the United States is institutionally grounded. They use the nation's core values to construct their Muslim identity as an American identity. Their nationality is American. They are not using the ideals of religious freedom to say that they have a right to be Muslim. They are saying instead that they are Americans. They are not attached to the ethnic cultures of their parents, nor are those cultures the foundation for their religious identity. Their religious identity is constructed inside of their American lives. Their national identity is American and their religious identity is Muslim. Their national identity empowers the expression of their religious identity.

A transnational social field analysis is important in revealing that being an American is central to the identity of second-generation Muslims in the United States. The national and global conflicts around Islam raise significant questions about the citizenship of Muslims in Western nations. Research has made the case for the negative impact of anti-terrorism policies on second-generation Muslim Americans. Assumptions that religious identity trumps national identity or that it at least poses problems for social participation are at the center of national and global security policies that target Muslims. In nations such as the United States that are founded on religious diversity that is represented in Christian denominations, recognizing that nationality is not hindered by non-Christian religious identity is extremely important. Clearly, the above analysis demonstrates that second-generation Muslims in the United States are Americans.

Conflicts of Interest: The author declares no conflicts of interest.

\section{References}

Abdelhady, Dalia. 2006. Beyond Home/Host Networks: Forms of Solidarity Among Lebanese Immigrants in a Global Era. Indentities: Global Studies in Culture and Power 13: 427-53. [CrossRef]

Ahmad, Muneer. 2011. Homeland Insecurities: Racial Violence the Day after September 11. Race/Ethncity: Multidisciplinary Global Contexts 4: 337-50. [CrossRef]

Al-Ali, Nadje. 2002. Gender relations, transnational ties and rituals among Bosian refugees. Global Networks 2: 249-62. [CrossRef] 
Alimahomed, Sabrina. 2011. Generation Islam: Arab American Muslims and Racial Politics after September 11. Race/Ethncity: Multidisciplinary Global Context 4: 381-97. [CrossRef]

Anthias, Floya. 2008. Thinking Through the Lens of Translocational Positionality: An Intersectional Frame for Understanding Identity and Belonging. Translocations: Migration and Social Change 4: 5-20.

Anthias, Floya. 2012. Transnational Mobilities, Migration Research and Intersectionality: Towards a Translocational Frame. Nordic Journal of Migration Research 2: 102-10. [CrossRef]

Berkhus, Wayne H. 2008. Trends in the Qualitative Study of Identities. Sociology Compass 2: 1059-78. [CrossRef]

Binaisa, Naluwembe. 2013. Ugandans in Britain Making 'New' Homes: Transnationalism, Place and Identity within Narratives of Integration. Journal of Ethnic and Migrations Studies 39: 885-902. [CrossRef]

Bowen, John R. 2004. Beyond Migration: Islam in Transnational Public Space. Journal of Ethnic and Migration Studies 30: 879-98. [CrossRef]

Brubaker, Rogers, and Frederick Cooper. 2000. Beyond "Identity". Theory and Society 29: 1-47. [CrossRef]

Cadge, Wendy, and Elaine Howard Ecklund. 2007. Immigration and Religion. Annual Review of Sociology 33: 259-379. [CrossRef]

Cainkar, Louise. 2004. Islamic Revival among Second-Generation Arab American Muslims: The American Experience and Global Intersect. Bulletin of the Royal Institute for Inter-Faith Studies 6: 99-120.

Cainkar, Louise, and Sunaina Maira. 2005. Targeting Arab/ Muslim/South Asian Americans: Criminalization and Cultural Citizenship. Ameriasia Journal 31: 1-28. [CrossRef]

Collins, Patricia Hill. 2000. Black Feminist Thought: Knowledge, Consciousness and the Politics of Empowerment. New York: Routledge. New York: Routledge.

Collins, Patricia Hill, and Sirma Bilge. 2016. Intersectionality. Cambridge: Polity.

Crenshaw, Kimberle. 1991. Mapping the Margins: Intersectionality, Identity Politics, and Violence against Women of Color. Stanford Law Review 43: 1241-99. [CrossRef]

Das Gupta, Monisha. 1997. What is Indian about You? A Gendered, Transnational Approach to Ethnicity. Gender and Society 11: 572-96. [CrossRef]

Easthope, Hazel. 2009. Fixed Identities in a Mobile World? The Relationship Between Mobility, Place and Identity. Identities: Global Studies in Culture and Power 16: 61-82. [CrossRef]

Faist, Thomas. 2000. Transnationalization in International Migration: Implications for the Study of Citizenship and Culture. Ethnic and Racial Studies 23: 189-223. [CrossRef]

Fouron, Georges, and Nina Glick Schiller. 2001. All in the family: Gender, transnational migration and the nation-state. Identities: Global Studies in Culture and Power 7: 539-82. [CrossRef]

Gardner, Katy, and Ralph Grillo. 2002. Transnational households and ritual: An overview. Global Networks 2: 179-90. [CrossRef]

Gergen, Kenneth J., and Mary M. Gergen. 2007. Social Construction and Research Methodology. In The Sage Handbook of Social Science Methodology. Edited by Willam Outhwaite and Stephen P. Turner. New York: Sage Publicationa, pp. 461-78.

Grammich, Clifford, Kirk Hadaway, Richard Houseal, Dale E. Jones, Alexei Krindatch, Richie Stanley, and Richard H. Taylor. 2010. US Congregation Membership Reports: Philadelphia County. Available online: http://www.thearda.com/rcms2010/r/c/42/rcms2010_42101_county_cong_2010.asp. (accessed on 27 August 2013).

Grillo, Ralph. 2004. Isalm and Transnationalism. Journal of Ethnic and Migrations Studies 30: 861-78. [CrossRef]

Haddad, Yvonne Yazbeck, and Adair T. Lummis. 1987. Islamic Values in the United States: A Comparative Study. New York: Oxford University Press.

Heath, Anthony. 2014. Introduction: Patterns of generational change: Convergence, reactive or emergent. Ethnic and Racial Studies 37: 1-9. [CrossRef]

Henkel, Heiko. 2004. Rethinking the dar al-harb: Social Change and the Changing Preceptions of the West in Turkish Islam. Journal of Ethnic and Migration Studies 30: 961-77. [CrossRef]

Kibria, Nazli. 2008. The 'new Islam' and Bangladeshi Youth in Britain and the U.S. Ethnic and Racial Studies 31: 243-66. [CrossRef]

Lacroix, Thomas. 2014. Conceptualizing Transnational Engagements: A Structure and Agency Perspective on (Hometown) Transnationalism. International Migration Reveiw 48: 643-79. [CrossRef]

Lawler, Steph. 2008. Identity: Sociological Prepsectives. Cambridge: Polity. 
Levitt, Peggy, and B. Nadya Jaworsky. 2007. Transnational Migration Studies: Past Develpments and Future Trends. Annual Review of Sociology 33: 129-56. [CrossRef]

Levitt, Peggy, and Nina Glick-Schiller. 2004. Conceptualizing Simultaneity: A Transnational Social Field Perspective on Society. The International Migration Review 38: 1002-39. [CrossRef]

Peggy Levitt, and Mary C. Waters, eds. 2002. Introduction. In The Changing Face of Home: Transnationalism in the Lives of the Second Generation. New York: Russell Sage Foundation, pp. 1-30.

Louie, Vivian. 2006. Growing Up Ethnic in Transnational Worlds: Identities among Second-Generation Chinese and Dominicans. Identities: Global Studies in Culture and Power 13: 363-94. [CrossRef]

Maira, Sunaina. 2004. Youth Culture, Citizenship and Globalization: South Asain Muslim Youth in the United States after September 11. Comparative Studies of South Asia, Africa and the Middle East 24: 219-31. Available online: http:/ / muse.jhu.edu/journals/cst/summary/v024/24.1maira.html (accessed on 12 September 2007). [CrossRef]

Maira, Sunaina. 2008. Flexible Citizenship/ Flexible Empire: South Asian Muslim Youth in Post-9/11 America. American Quarterly 60: 697-720. [CrossRef]

Mandaville, Peter. 2009. Muslim Transnational Identity and State Responses in Europe and the UK after 9/11: Political Community, Ideology and Authority. Journal of Ethnic and Migration Studies 35: 491-506. [CrossRef]

Mandaville, Peter. 2011. Transnational Muslim Solidarities and Everyday Life. Nations and Nationalism 17: 7-21. [CrossRef]

McAuliffe, Cameron. 2007. A home far away? Religious identity and transnational relations in the Iranian diaspora. Global Networks 7: 307-27. [CrossRef]

Mirza, Heidi. 2013. 'A Second Skin': Embodoes Intersectionality, Transnationalism and Narratives of Identity and Belonging among Muslim Women in Britain. Women's Studies International Forum 36: 5-15. [CrossRef]

Naber, Nadine. 2000. Ambiguous Insiders: An Investigation of Arab American Invisibility. Ethnic and Racial Studies 23: 37-61. [CrossRef]

Osirim, Mary Johnson. 2011. Transnational Migration and Transformation Among African Women in the United States: Change-agents Locally and Globally. Advances in Gender Research 15: 185-210.

Pew Forum on Religion and Public Life. 2007. Muslim Americans: Middle Class and Mostly Mainstream. Washington: Pew Research Center.

Pew Forum on Religion and Public Life. 2011. Muslim Americans: No Signs of Growth in Alienation or Sopport for Extremism. Washington: Pew Research Center, Available online: http://www.people-press.org/ 2011/08/30/muslim-americans-no-signs-of-growth-in-alienation-or-support-for-extremism/ (accessed on 22 March 2015).

Purkayastha, Bandana. 2010. Interrogating Intersectionality: Contemporary Globalisation and Racialised Gendering in the Lives of Highly Educated South Asian Americans and their Children. Journal of Intercultural Studies 31: 29-47. [CrossRef]

Purkayastha, Bandana. 2012. Intersectionality in a Transnational World. Gender and Society 26: 55-66. [CrossRef]

Salih, Ruba. 2004. The Backward and the New: National, Transnational, and post-national Islam in Europe. Journal of Ethnic and Migration Studies 30: 995-1011. [CrossRef]

Schimmer, Paulien, and Frank van Tubergen. 2014. Transnationalism and Ethnic Identification among Adolescent Children of Immigrants in the Netherlans, Germany, England, and Sweden. International Migration Reveiw 48: 680-709. [CrossRef]

Schmidt, Garbi. 2004. Islamic Identity Formation among Young Muslims: The Case of Denmark, Sweden, and the United States. Journal of Muslim Minority Affairs 24: 31-45. [CrossRef]

Thomson, Mark, and Maurice Crul. 2007. The Second Generation in Europe and the United States: How is the Transnational Debate Relevant for Future Research on the European Second Generation. Journal of Ethnic and Migration Studies 33: 1025-41. [CrossRef]

Tilly, Charles. 2003. Political Identitys in Changing Politics. Social Research 70: 606-20.

Vertovec, Steven. 2001. Transnationalism and Identity. Journal of Ethnic and Migration Studies 27: 573-82. [CrossRef] Viruell-Fuentes, Edna A. 2006. My Heart is Always There: The Transnational Practices of First-Generation Mexican Immigrant and Second-Generation Mexican American Women. Identities: Global Studies in Culture and Power 13: 335-62. [CrossRef]

Voas, David, and Fenella Fleischmann. 2012. Islam Moves West: Religious Change in the First and Second Generations. Annual Review of Sociology 38: 525-45. [CrossRef] 
Waldinger, Roger, and David Fitzgerald. 2004. Transnationalism in Question. American Journal of Sociology 109: 1177-95.

Waters, Mary C. 2014. Defining difference: The role of immigrant generation and race in American and British immigrantion studies. Ethnic and Racial Studies 37: 10-26. [CrossRef]

Wuthnow, Robert, and Stephen Offutt. 2008. Transnational Religious Connections. Sociology of Religion 69: 209-32. [CrossRef]

Zevallos, Zuleyka. 2008. 'You Have to be Anglo and Not Look Like Me': Identity and belonging among young wome of Turkish and Latin American backgrounds in Melbourne Australia. Australian Geographer 39: 21-43. [CrossRef]

(c)

(C) 2017 by the author. Licensee MDPI, Basel, Switzerland. This article is an open access article distributed under the terms and conditions of the Creative Commons Attribution (CC BY) license (http:/ / creativecommons.org/licenses/by/4.0/). 